\title{
Effectiveness of vibration energy harvesting for wireless loT devices
}

\author{
Efektywność pozyskiwania energii z drgań \\ dla bezprzewodowych urządzeń loT
}

\author{
PIOTR SZULEWSKI \\ MIROSŁAW NEJMAN \\ JERZY RAPCEWICZ \\ DOMINIKA ŚNIEGULSKA-GRĄDZKA*
}

DOI: https://doi.org/10.17814/mechanik.2021.11.15

\begin{abstract}
With the advent and more common use of wireless sensors, the issue of their power supply becomes really important. An interesting problem is the possibility of obtaining energy from the environment because this energy could be used to power remote sensors installed in any location and fully energy independent. The key question is the actual efficiency of energy conversion by a specialized transducer, directly affecting the area of possible applications of such an energy source. The article presents basic technical information on the construction and principles of operation of vibration/ /voltage transducers. Also describes the conducted tests of the behaviour of a selected transducer in controlled laboratory conditions (vibrator) and in real conditions of vibrations generated by a moving train. The results document the expected dependence of the amount of generated energy on the type of vibrations to which the transducer is exposed. KEYWORDS: energy harvesting, power source loT, vibration, transducer effectiveness, railway
\end{abstract}

Wraz z pojawieniem się i rozpowszechnieniem czujników bezprzewodowych istotne stało się zagadnienie ich zasilania. Ciekawym rozwiązaniem jest możliwość pozyskiwania energii $z$ otoczenia/środowiska, ponieważ energia ta mogłaby być wykorzystana do zasilania bezprzewodowych urządzeń loT (internetu rzeczy) instalowanych w dowolnej lokalizacji i w pełni niezależnych energetycznie. Kluczową niewiadomą jest rzeczywista ilość energii wytwarzanej przez specjalizowany przetwornik bezpośrednio wpływająca na możliwości zastosowania takiego źródła energii. W artykule przedstawiono podstawowe informacje techniczne dotyczące budowy i zasady działania przetworników drgania/ /napięcie oraz opisano przeprowadzone badania charakterystyki pracy wybranego przetwornika w kontrolowanych warunkach laboratoryjnych (ze wzbudnikiem drgań) i w warunkach rzeczywistych, w których drgania były generowane przez przemieszczający się pociąg. Otrzymane wyniki dokumentują spodziewaną zależność ilości wytwarzanej energii od rodzaju drgań, jakim poddawany jest przetwornik.

SŁOWA KLUCZOWE: zasilanie niekonwencjonalne, zasilnie IoT, wibracje, przetwornik drgania/napięcie, kolej

\section{Wprowadzenie}

Energia w świecie fizycznym występuje pod różnymi postaciami, które mogą być identyfikowane na podstawie skutków jej działania. Ważną cechą energii jest możliwość jej przemiany. Można wyróżnić trzy procesy energetyczne:

- przemianę postaci energii zwaną konwersją energii, - przenoszenie energii zwane transmisją,

- zamianę energii na pracę lub odwrotnie.

Podstawowym prawem opisującym właściwości energii jest zasada zachowania energii. Zgodnie z nią suma wszystkich rodzajów energii w układzie izolowanym jest stała [1]. Z tego prawa wynika, że powinna być zachowana równość energii wprowadzonej do systemu $E_{\text {wej }}$ z energią wyjściową $E_{\text {wyj }}$ oraz częścią energii $E_{\text {str }}$, która jest tracona w procesie przemiany. System energetyczny można zatem opisać w następujący sposób:

$$
E_{\text {wej }}=E_{\text {wyj }}+E_{\text {str }}
$$

Występujące w równaniu (1), nieuniknione straty energii (zależne od sprawności funkcjonowania systemu) są wyrażane wartością sprawności energetycznej $\eta$, która jest określana jako stosunek $E_{\text {wyj }}$ do $E_{\text {wej. }}$ Ponieważ $E_{\text {wyj }}<E_{\text {wej }}$, więc współczynnik ma zawsze wartość $\eta<1$.

Dla prawidłowego funkcjonowania najróżniejszych urządzeń konieczne jest dostarczanie odpowiedniej ilości energii - w obecnych warunkach najczęściej w postaci prądu elektrycznego, często traktowanego jako uniwersalny nośnik. Typowymi źródłami prądu elektrycznego dla odbiorników są baterie, akumulatory, ogniwa lub stałe linie zasilające. Jednak wiele urządzeń pracuje w środowiskach ze swej natury oferujących pewien zasób „nadmiarowej” energii, którą można wykorzystać do niezbędnego zasilania układów pomiarowych, sterujących lub wykonawczych. Tego typu działania, zmierzające do pozyskiwania

\footnotetext{
* Dr inż. Piotr Szulewski, piotr.szulewski@pw.edu.pl, https://orcid.org/0000-0002-0821-3946 - Instytut Technik Wytwarzania Politechniki Warszawskiej, Warszawa, Polska

Dr inż. Mirosław Nejman, miroslaw.nejman@pw.edu.pl, https://orcid.org/0000-0003-4418-019X - Instytut Technik Wytwarzania Politechniki Warszawskiej, Warszawa, Polska

Mgr inż. Jerzy Rapcewicz, jerzy.rapcewicz@pw.edu.pl, https://orcid.org/0000-0001-7607-7141 - Instytut Technik Wytwarzania Politechniki Warszawskiej, Warszawa, Polska

Dr inż. Dominika Śniegulska-Grądzka, dominika.gradzka@pw.edu.pl, https://orcid.org/0000-0001-6418-5938 - Instytut Technik Wytwarzania Politechniki Warszawskiej, Warszawa, Polska
} 
energii z otoczenia i - po niezbędnym przetworzeniu - do planowego jej wykorzystania, są nazywane: „odzyskiwaniem energii”, „zasilaniem energią ogólnie dostępną", „energią pozyskiwaną" lub w literaturze anglojęzycznej - "harvesting energy" [2]. Funkcjonuje też nazwa „odnawialne źródła energii” (OZE).

Dostępne techniczne przetworniki pozwalają na wykorzystywanie niekonwencjonalnych źródeł, takich jak: miniaturowe ogniwa słoneczne, generatory piezo, elektromagnetyczne, termoelektryczne, źródła energii pochodzenia biologicznego lub energia z pola elektrycznego, a także energia drgań mechanicznych (naprężeń lub odkształceń) w szerokim zakresie częstotliwości $[3,4]$. Technologia miniaturyzacji umożliwia budowanie przetworników w formie układów MEMS (microelectromechanical system, co oznacza systemy mikroelektromechaniczne wykorzystywane w elektronice użytkowej, urządzeniach medycznych i czujnikach przemysłowych) [5]. Technika ta integruje komponenty mechaniczne, elektronikę, czujniki i siłowniki na materiale półprzewodnikowym, chipie lub płytce [6]. Sposób uzyskania energii elektrycznej za pomocą specjalizowanego przetwornika przedstawiono na rys. 1.

Urządzenia do odzyskiwania energii z otoczenia są intensywnie badane $\mathrm{w}$ ciągu ostatnich kilkunastu lat, głównie ze względu na potrzebę zasilania urządzeń bezprzewodowych lub stworzenia autonomicznych rozwiązań energetycznych [7]. W środowiskach przemysłowych powszechnie występującym zjawiskiem, nierozerwalnie związanym z przemieszczaniem, obrotami czy działaniem zmiennych sił, są drgania będące zazwyczaj zjawiskiem niepożądanym i trudnym do usunięcia. Stąd wynika naturalna chęć wykorzystania drgań jako praktycznie niewyczerpywalnego źródła energii dla układów pomiarowych, sterujących lub IoT [8]. Na rys. 2 zaprezentowano przykład wykorzystania takiego źródła energii do zasilania niewielkiego systemu pomiarowego.

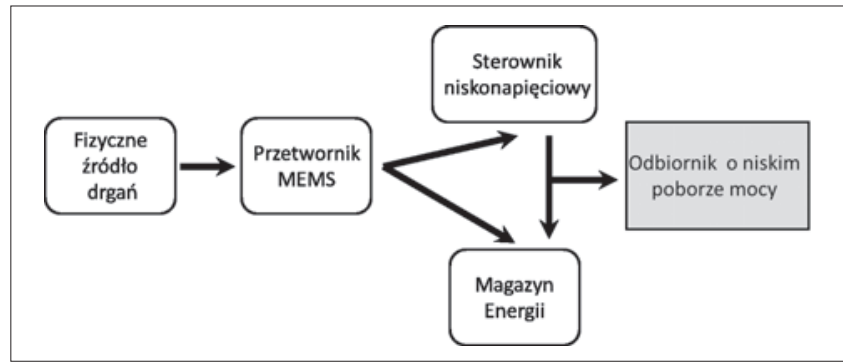

Fig. 1. The operation diagram of an unconventional power supply Rys. 1. Schemat działania zasilacza niekonwencjonalnego

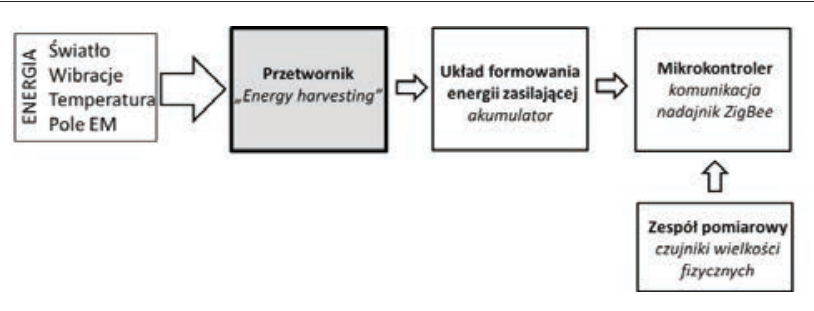

Fig. 2. Schematic diagram of a set of sensors with independent power supply

Rys. 2. Schemat ideowy zespołu czujników z niezależnym zasilaniem

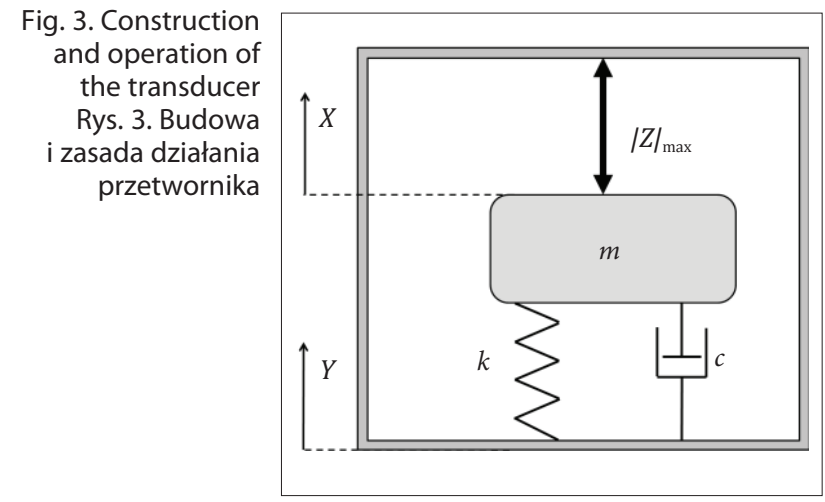

Niezależność w wytwarzaniu energii koniecznej do poprawnego funkcjonowania zespołu czujników pozwala na ich swobodne instalowanie w dowolnych lokalizacjach, w których występują zjawiska mogące dostarczyć energię do przetwornika $[9,10]$. Przykładowy schemat przetwornika drgania/napięcie zaprezentowano na rys. 3. Jest to konstrukcja układu masowo-sprężysto-tłumiącego, gdzie wprawiana w ruch masa sejsmiczna dostarcza energię do elementu przetwarzającego (np. piezoelektrycznego, elektromagnetycznego).

Na rys. 3 zaznaczono odpowiednio: $X$ - układ odniesienia przetwornika (obudowy), $Y$ - układ odniesienia masy pomiarowej przetwornika, $|Z|_{\max }$ - wartość bezwzględną dopuszczalnego przemieszczenia masy pomiarowej, $k$ - sztywność, $c$ - współczynnik tłumienia, $m$ - masę pomiarową przetwornika.

Sercem wielu urządzeń tego typu jest liniowy układ masowo-sprężysto-tłumiący o jednym stopniu swobody. Służy on do wzmacniania drgań o określonej częstotliwości $[11,12]$, przy czym oscylator jest na ogół tak dostrojony, aby jego częstotliwość własna była równa częstotliwości wzbudzenia, a tłumienie było jak najmniejsze. Sygnał wejściowy do układu przetwornika (sygnał wzbudzenia) stanowi przyśpieszenie, któremu jest poddawany cały układ poprzez sztywną obudowę. Ogólnie zakłada się, że drgania urządzenia do pozyskiwania energii nie wpływają na drgania obiektu (wymagana jest możliwie duża różnica mas, co oznacza niezmienność amplitudy i częstotliwości drgań). Dodatkowo dla uproszczenia przyjmuje się, że uzyskana $\mathrm{w}$ przetworniku energia jest taka sama jak energia rozpraszana przez amortyzator, co jest możliwe jedynie w przypadku braku strat mechanicznych. Ze względu na zamknięcie przetwornika w sztywnej obudowie jego maksymalne przemieszczenie względne masy jest ograniczone do wartości $|Z|_{\max }$, gdzie prawdziwe jest równanie: $Z=X-Y$ określające przemieszczenie względne między masą $X$ a obudową $Y$. Równanie ruchu (2) przetwornika jest określone wzorem:

$$
m \ddot{z}+c \dot{z}+k z=-m \ddot{y}
$$

gdzie wielkości: $m, k$ i $c$ oznaczają odpowiednio: masę, sztywność i tłumienie, natomiast: $z, \dot{z}, \ddot{z}$ oznaczają pochodną po czasie, czyli: przemieszczenie, prędkość i przyśpieszenie. Energia wytworzona w czasie $t_{\mathrm{e}}$ jest dana ze wzoru: 


$$
E\left(t_{\mathrm{e}}\right)=\int_{0}^{t_{\mathrm{e}}} c \dot{z}^{2} d t
$$

Większość wcześniejszych badań dotyczących pozyskiwania energii z drgań koncentrowała się na sytuacjach, $w$ których energia jest magazynowana przez wystarczająco długi czas, aby początkowa odpowiedź przejściowa oscylatora była pomijalna w porównaniu $\mathrm{z}$ odpowiedzią w stanie ustalonym [13]. Jeśli jednak tłumienie w przetworniku jest niskie, co może mieć miejsce $\mathrm{w}$ przypadku zwiększenia energii zbieranej w każdym cyklu, w rezultacie wystąpi stosunkowo długi początkowy stan przejściowy, zanim system osiągnie stan ustalony. Jest to główne ograniczenie, gdy występuje pobudzenie ograniczone w czasie [14]. Początkowy stan nieustalony może mieć szkodliwy wpływ na wydajność całego układu generowania energii elektrycznej, jeśli rozważy się klasyczne podejście projektowe oparte na zachowaniu w stanie ustalonym [15]. Dlatego właśnie tak ważne wydawało się przeprowadzenie badań w rzeczywistym środowisku, w którym nie ma możliwości „programowania” pojawiających się drgań optymalnych dla pracy przetwornika (wytworzona energia jest implikowana stochastycznymi parametrami sił wymuszających). Zdecydowano się na środowisko kolejowe gwarantujące szerokie spektrum drgań (w dziedzinie czasu i częstotliwości) i całkowitą zmienność warunków pracy.

\section{Przetwornik}

Do badań wybrano przetwornik szwedzkiej firmy ReVibe Energy model D v5, polecany przez producenta zwłaszcza do instalacji prototypowych i badawczych. Głównymi argumentami wyboru były: gwarantowana wysoka sprawność przetwarzania energii, brak układów kształtujących wartość i kształt napięcia wyjściowego, łatwość mocowania wynikająca z przemyślanego kształtu i znacznych wymiarów geometrycznych, trwała obudowa (także hermetyczność) przystosowana do pracy w trudnych warunkach otoczenia oraz szeroki zakres temperatur pracy (od $-20^{\circ} \mathrm{C}$ do $60^{\circ} \mathrm{C}$ ). Podstawowe parametry zestawiono w tabl. I.

TABLE I. Technical specification of ReVibe Energy model D v5 [16] TABLICA I. Specyfikacja techniczna ReVibe Energy model D v5 [16]

\begin{tabular}{|l|c|}
\hline \multicolumn{2}{|c|}{ Specyfikacja techniczna } \\
\hline Docelowa częstotliwość & $150 \mathrm{~Hz}( \pm 1 \mathrm{~Hz})$ \\
\hline Wymiary & $H 57,5 \mathrm{~mm} \varnothing 33 \mathrm{~mm}$ \\
\hline Masa & $135 \mathrm{~g}$ \\
\hline Wyjście & $\begin{array}{c}\text { nieuregulowany prąd zmienny } \\
\text { (opcjonalnie 2,5 } \pm 5 \mathrm{~V} \text { DC) }\end{array}$ \\
\hline $\begin{array}{l}\text { Referencyjne obciążenie } \\
\text { elektryczne }\end{array}$ & $1000 \Omega$ \\
\hline
\end{tabular}

Jak wspomniano we wprowadzeniu, w tego typu przetwornikach z ruchomą masą sejsmiczną istotnym parametrem - ustawianym przez producenta - jest wartość częstotliwości drgań własnych. W omawianym przypadku zdecydowano się na wartość $150 \mathrm{~Hz}$, największą jaka jest oferowana. Przyjmując tę wartość, założono efektywną pracę przetwornika także w szerszym zakresie częstotliwości (choć należy wspomnieć, że zalecany zakres to $\pm 15 \mathrm{~Hz}$ ustawionej częstotliwości rezonansowej). Producent podaje opracowaną we własnych laboratoriach wydajność przetwarzania drgań na energię elektryczną. Dane te przedstawiono w tabl. II.

TABLE II. Transducer performance parameters [16] TABLICA II. Parametry wydajności przetwornika [16]

\begin{tabular}{|c|c|}
\hline \multicolumn{2}{|c|}{ Parametry wydajności } \\
\hline Przyspieszenie wejściowe $60 \mathrm{~Hz}$ & Moc wyjściowa \\
\hline $0,05 \mathrm{~g}$ & $1 \mathrm{~mW}$ \\
\hline $0,1 \mathrm{~g}$ & $4,5 \mathrm{~mW}$ \\
\hline $0,5 \mathrm{~g}$ & $70 \mathrm{~mW}$ \\
\hline $1 \mathrm{~g}$ & $150 \mathrm{~mW}$ \\
\hline $3 \mathrm{~g}$ & $300 \mathrm{~mW}$ \\
\hline
\end{tabular}

Podane parametry zostały potraktowane jako wartości maksymalne, możliwe do osiągnięcia jedynie w idealnych warunkach pracy przetwornika i mogące stanowić punkt odniesienia $w$ realizowanych badaniach. Przykładowo dla najmniejszych możliwych wartości podanych przez producenta minimalna wartość natężenia prądu powinna wynosić:

$$
I=\frac{P}{U}=\frac{1 \mathrm{~mW}}{2,8 \mathrm{~V}}=0,36 \mathrm{~mA}
$$

gdzie: $I$ - prąd, $P$ - moc, $U$ - napięcie.

Na rys. 4 pokazano przetwornik zamocowany do wzbudnika laboratoryjnego, wzorcowego generatora drgań mechanicznych. Oznaczenia: 1 - wzbudnik typu 4812 firmy Brüel \& Kjær, 2 - przetwornik firmy ReVibe Energy, 3 - stalowa płytka adaptera do zamocowania przetwornika, 4 - akcelerometr firmy Kistler. Przetwornik został zamontowany do sterowanego wzbudnika drgań, tak jak zostało to zalecone w instrukcji i jak będzie pracować w warunkach polowych.

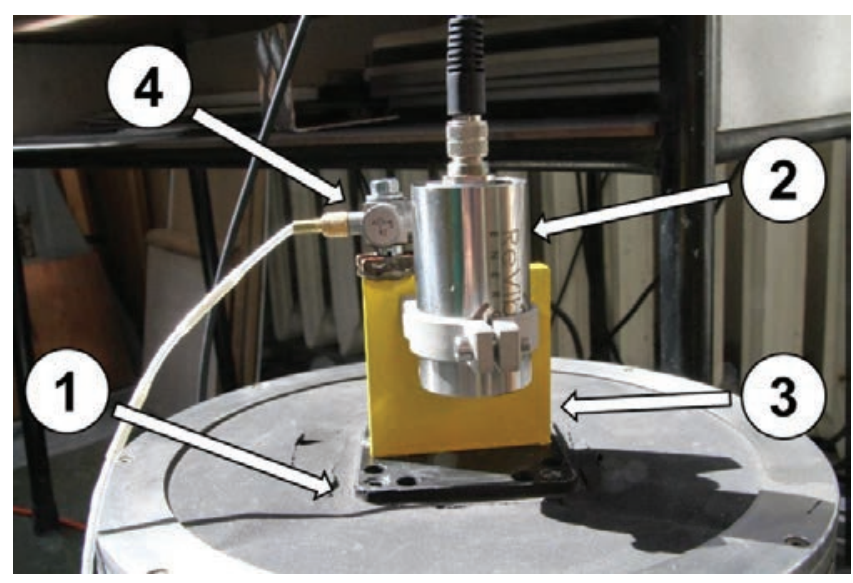

Fig. 4. Construction and operation of the transducer Rys. 4. Budowa i zasada działania przetwornika 


\section{Badania laboratoryjne}

W celu określenia realnych parametrów pracy przetwornika przeprowadzono badania $\mathrm{w}$ kontrolowanym i sterowanym środowisku laboratoryjnym. Eksperymenty zostały wykonane za pomocą wzorcowego wzbudnika drgań typu 4812 firmy Brüel \& Kjær. Przetwornik był zamocowany do specjalnie zaprojektowanej płytki montażowej umieszczonej na drgającym elemencie wzbudnika drgań. Wzbudnik był zasilany z przestrajanego układu sterującego.

Jak wspomniano, bazowa częstotliwość pracy przetwornika (częstotliwość rezonansowa) wynosi $150 \mathrm{~Hz}$. Pomiary zostały wykonane w zakresie częstotliwości od $50 \mathrm{~Hz}$ do $260 \mathrm{~Hz}$. Podczas wzbudzania przetwornika prowadzono stały pomiar generowanej wartości prądu oraz napięcia. Jako obciążenie zastosowano układ o charakterystyce rezystancyjnej w postaci opornika bezindukcyjnego o wartości $1 \mathrm{k} \Omega$. Pomiary napięcia i natężenia zostały wykonane multimetrem laboratoryjnym Brymen 837 oraz miernikiem laboratoryjnym Appa 207. Stanowisko pomiarowe pokazano na rys. 5.

W celach kontrolnych do wzbudnika dołączono kwarcowy akcelerometr trójosiowy firmy Kistler typu 8729A50, mierzący przyśpieszenia w trzech wzajemnie prostopadłych osiach o zakresach pomiarowych $\pm 50 \mathrm{~g}$ w każdej osi. Zamocowano go za pomocą magnetycznej podstawki do szybkiego montażu. Pełnił on rolę referencyjną, pozwalającą na weryfikację rzeczy-

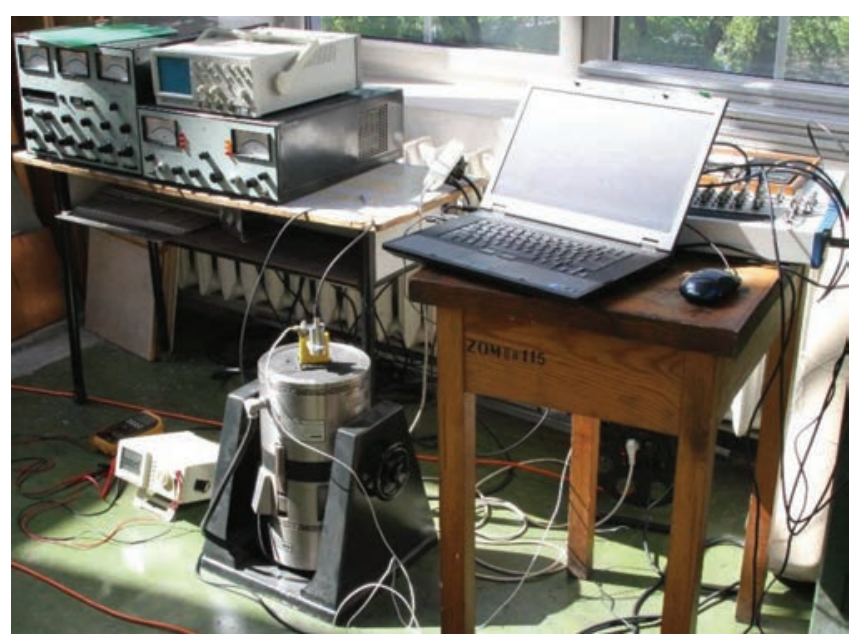

Fig. 5. Complete measuring station of the transducer Rys. 5. Kompletne stanowisko pomiarowe przetwornika

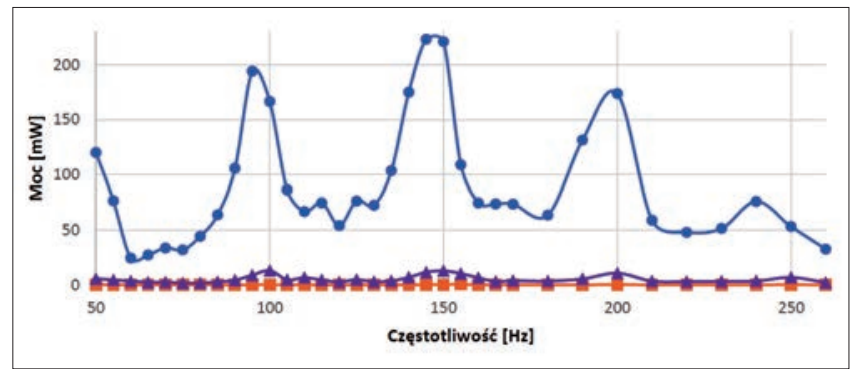

Fig. 6. Electric power generated by the transducer as a function of frequency

Rys. 6. Moc elektryczna generowana przez przetwornik w funkcji częstotliwości wistych wartości amplitudy, częstotliwości generowanych drgań, a także osiąganych przyśpieszeń. Sygnały z czujnika były przetwarzane w czasie rzeczywistym za pomocą programu NI Signal Express i oprogramowania przeznaczonego do tego zadania, opracowanego samodzielnie w środowisku LabView. Pomiary wykonano dla częstotliwości drgań od $50 \mathrm{~Hz}$ do $260 \mathrm{~Hz}$. W zakresie od 50 do $170 \mathrm{~Hz}$ pomiary były wykonywane z krokiem $5 \mathrm{~Hz}$, po czym następne pomiary wykonano co $10 \mathrm{~Hz}$. Na rys. 6 zamieszczono wykres mocy generowanej przez przetwornik $\mathrm{w}$ funkcji częstotliwości drgań.

Moc została obliczona ze wzoru:

$$
P[\mathrm{~mW}]=U[\mathrm{~V}] \cdot I[\mathrm{~mA}]
$$

gdzie: napięcie i natężenie prądu w obwodzie zostały zmierzone za pomocą multimetrów laboratoryjnych.

Największe wartości mierzonych wielkości zarejestrowano dla zakresu częstotliwości $145 \div 155 \mathrm{~Hz}$ (co jest zgodne z zaleceniami producenta), wskazującym na częstotliwość rezonansową badanego egzemplarza przetwornika wynoszącą $150 \mathrm{~Hz}$. W tabl. III zestawiono zarejestrowane wartości maksymalne.

TABLE III. The measured maximum values of voltage and current generated by the transducer in the frequency range $145 \div 155 \mathrm{~Hz}$ TABLICA III. Zmierzone maksymalne wartości napięcia i natężenia prądu generowanego przez przetwornik w zakresie częstotliwości $145 \div 155 \mathrm{~Hz}$

\begin{tabular}{|c|c|c|r|}
\hline $\begin{array}{c}\text { Amplituda } \\
\text { drgań }\end{array}$ & $\begin{array}{c}\text { Napięcie } \\
{[\mathrm{V}]}\end{array}$ & $\begin{array}{c}\text { Natężenie } \\
{[\mathrm{mA}]}\end{array}$ & $\begin{array}{c}\text { Moc } \\
{[\mathrm{mW}]}\end{array}$ \\
\hline mała & 0,66 & 0,7 & 0,46 \\
\hline średnia & 3,57 & 3,61 & 12,89 \\
\hline duża & 14,67 & 15,22 & 223,28 \\
\hline
\end{tabular}

W tabl. IV zamieszczono wyniki pomiarów dla częstotliwości wymuszenia $65 \mathrm{~Hz}$, bardzo odległej od zalecanych $150 \mathrm{~Hz}$. Porównując dane z tabl. III i tabl. IV, zaobserwowano znaczne zmniejszenie efektywności przetwarzania drgań mechanicznych w energię.

TABLE IV. Values of voltage and current generated by the transducer for the frequency of $65 \mathrm{~Hz}$

TABLICA IV. Wartości napięcia i natężenia prądu generowanego przez przetwornik dla częstotliwości $65 \mathrm{~Hz}$

\begin{tabular}{|c|c|c|c|}
\hline $\begin{array}{c}\text { Amplituda } \\
\text { drgań }\end{array}$ & $\begin{array}{c}\text { Napięcie } \\
{[\mathrm{V}]}\end{array}$ & $\begin{array}{c}\text { Natężenie } \\
{[\mathrm{mA}]}\end{array}$ & $\begin{array}{c}\text { Moc } \\
{[\mathrm{mW}]}\end{array}$ \\
\hline mała & 0,23 & 0,27 & 0,06 \\
\hline średnia & 1,57 & 1,61 & 2,53 \\
\hline duża & 5,15 & 5,31 & 27,35 \\
\hline
\end{tabular}

Zgodnie z informacjami podanymi przez producenta przetwornik powinien pracować $\mathrm{w}$ zakresie częstotliwości, do jakich został zaprojektowany i wykonany, jednak nawet podczas pracy $\mathrm{w}$ innych częstotliwościach jest w stanie wytworzyć niewielką ilość energii, choć wielokrotnie mniejszą od maksymalnej. Analizując otrzymane wyniki, można zauważyć prawidłowość, że im większa amplituda drgań, tym większe są wartości napięcia, natężenia i mocy. Zatem 
działanie przetwornika nie zależy jedynie od częstotliwości drgań, ale również od amplitudy tych drgań. Im większa częstotliwość oraz amplituda, tym większe wartości osiąga przetwornik.

\section{Badania polowe}

Jako środowisko testowe do badań efektywności pracy przetwornika drgania/napięcie wybrano obszar drgań tworzonych przez przejeżdżające pociągi. Gwarantowało to wzbudzanie przetwornika drganiami o losowych częstotliwościach i amplitudach - czyli praca odbywała się w warunkach trudnych, niezgodnych $\mathrm{z}$ zaleceniami producenta przetwornika. Jako wstęp do badań przeprowadzono jakościową i ilościową ocenę drgań szyn kolejowych wzbudzanych przez przejeżdżający pociąg, aby ocenić przydatność tychże wibracji do wzbudzania przetwornika.

Zjawisko drgań wywołanych ruchem pociągu można opisać jako propagację fali mechanicznej przez konstrukcję i grunt. Ma ono bardzo skomplikowaną naturę, w której można wyróżnić wiele elementów bezpośrednio i pośrednio wpływających na wynikowe przemieszczenia przetwornika. Przykładowo można wymienić: rodzaj zawieszenia pojazdu, stan kół, rodzaj powierzchni szyny, system podparcia podkładów, prędkość przejazdu, strukturę toru, położenie ośrodków transmisji wibracji, typ gleby, występowanie warstw skalnych, głębokość do lustra wód gruntowych, a nawet głębokość przemarzania gruntu.

Badania przeprowadzono z wykorzystaniem karty pomiarowej firmy National Instruments USB 6259 (16 analogowych wejść różnicowych, 48 wejść i wyjść cyfrowych, rozdzielczość 16 bitów, próbkowanie $1,25 \mathrm{mln} / \mathrm{s}$ - maksymalna częstotliwość sygnału $625 \mathrm{kHz}$ ) ze względu na możliwość prowadzenia pomiarów z dużymi częstotliwościami próbkowania, a także obsługi kanałów jako symetryczne lub niesymetryczne. Podczas wstępnych testów toru pomiarowego okazało się, że $\mathrm{w}$ pobliżu aparatury pomiarowej było wiele źródeł fal elektromagnetycznych powodujących zakłócenia $\mathrm{w}$ mierzonym sygnale i tylko możliwość konfiguracji pomiaru symetrycznego pozwoliła na eliminację większości z nich.
Fig. 7. View of the measurement point the place where the sensors are attached to the rail Rys. 7. Widok punktu pomiarowego miejsce mocowania czujników do szyny kolejowej

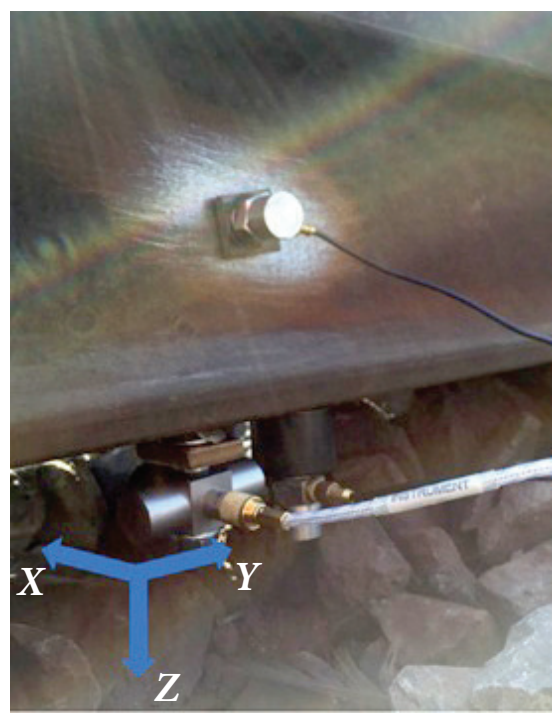

Wibracje były mierzone za pomocą akcelerometru trójosiowego firmy Kistler (8792A50, zakres pomiarowy $\pm 50 \mathrm{~g}$, czułość $100 \mathrm{mV} / \mathrm{g}$, jednoczesny pomiar udaru i przyspieszenia w trzech prostopadłych osiach, pasmo przenoszenia $0,5 \div 5 \mathrm{kHz}$ ) oraz dwóch akcelerometrów jednoosiowych Brüel \& Kjær (4343, akcelerometr nr 1: zakres maksymalny $5000 \mathrm{~g}$, czułość 8,97 mV/g lub 10,16 pC/g - nietłumiona częstotliwość własna $85 \mathrm{kHz}$; akcelerometr nr 2: zakres pomiarowy $\pm 5000 \mathrm{~g}$, czułość $9,25 \mathrm{mV} / \mathrm{g}$ lub $10,20 \mathrm{pC} / \mathrm{g}$, nietłumiona częstotliwość własna $85 \mathrm{kHz}$ ). Widok punktu pomiarowego przedstawiono na rys. 7.

Na rys. 7 zaznaczono przyjęte kierunki pomiarów. Akcelerometr jednoosiowy był zamocowany poziomo - przez cały czas pomiarów na podstawce magnetycznej, a drugi czujnik jednoosiowy najpierw był mocowany na podstawce magnetycznej, a potem $\mathrm{z}$ wykorzystaniem wosku pszczelego.

Aby wyznaczyć dominujące częstotliwości sygnałów (mające istotny wpływ na jakość pracy przetwornika drgania/napięcie), obliczono widmo częstotliwości dla każdego sygnału z akcelerometru. Wybrano do obliczeń okno 1-sekundowe, ustawiając początek obliczeń, gdy pierwsze koła pociągu znajdowały się nad czujnikami. Przykład zestawionego przebiegu zarejestrowanych sygnałów z użytych akcelerometrów zamieszczono na rys. 8.

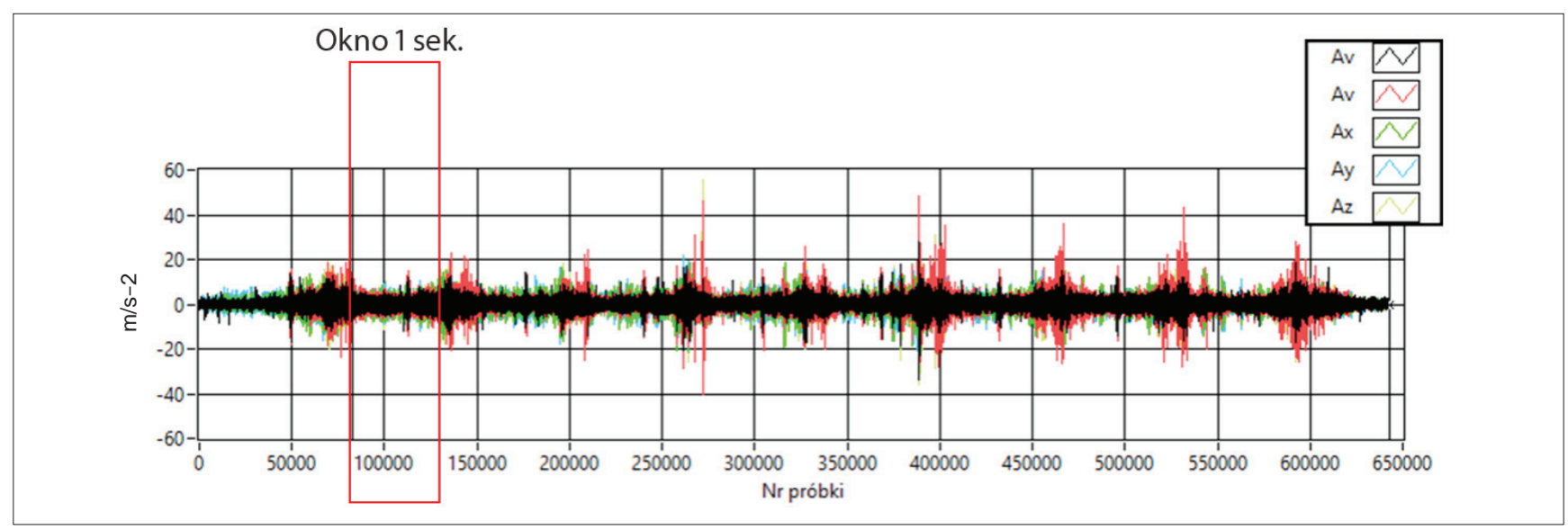

Fig. 8. Signals from accelerometers during the train journey Rys. 8. Sygnały z akcelerometrów podczas przejazdu pociągu 


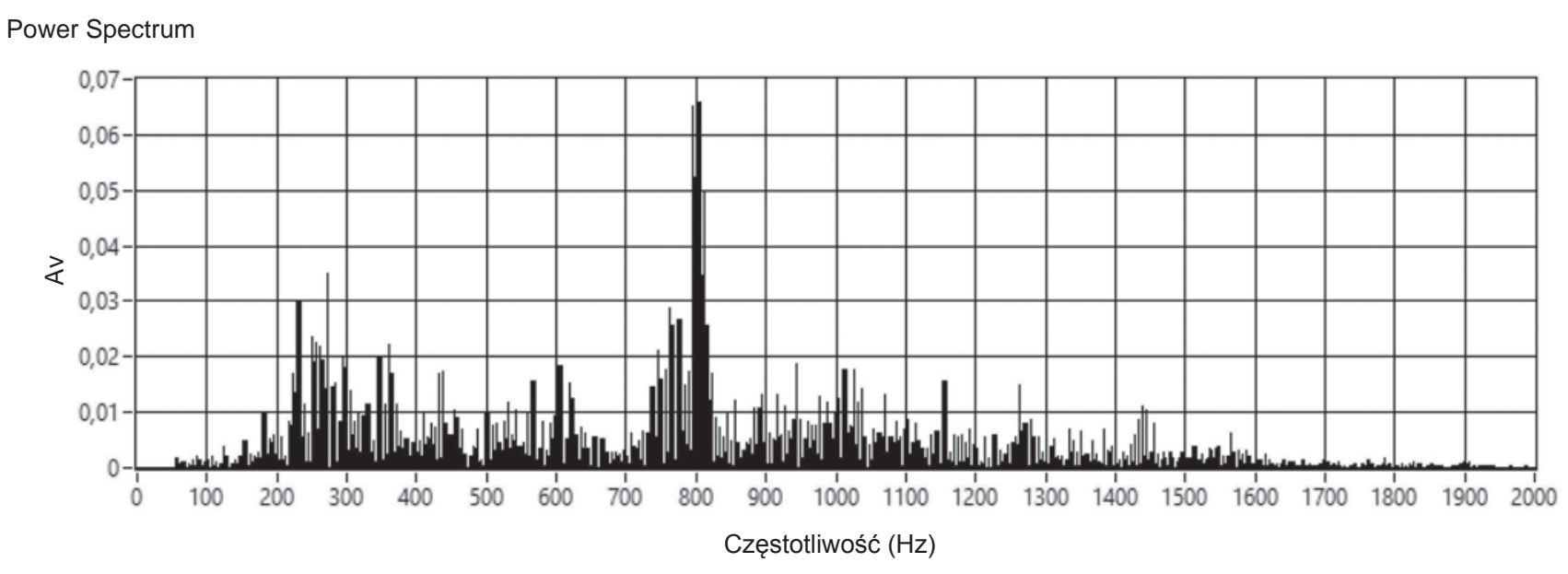

Fig. 9. Spectral analysis of the signal from the accelerometer Rys. 9. Analiza widmowa sygnału z akcelerometru

Widoczna na rys. 8 powtarzalność wzrostu wartości przyśpieszeń jest wynikiem wielokrotnego najazdu na punkt pomiarowy kół tocznych kolejnych wózków wagonowych. Przykład przeprowadzonej analizy widmowej pokazano na rys. 9. Rozdzielczość widma wynosi $1 \mathrm{~Hz}$.

Widać bardzo szeroki zakres częstotliwości drgań $(50 \div 1600 \mathrm{~Hz})$. W omawianym przypadku maksymalna amplituda występowała dla częstotliwości $800 \mathrm{~Hz}$. Otrzymane wyniki różniły się w zależności od rodzaju pociągu (masy, szybkości przejazdu, konstrukcji układu jezdnego itp.).

$\mathrm{Na}$ podstawie przeprowadzonych badań można skonstatować, że dominująca częstotliwość drgań wynosi około $450 \mathrm{~Hz}$. Dodatkowo w niektórych próbach widoczna jest wysoka wartość przyspieszeń dla częstotliwości około $650 \mathrm{~Hz}$. Należy zauważyć, że sposób mocowania czujników ma wpływ na postać wykrywanych drgań, co przekłada się na inną częstotliwość dominująca w sygnałach. Mocowanie na magnes $\mathrm{w}$ części prób daje około dwukrotnie wyższą częstotliwość dominującą niż w przypadku czujników mocowanych na wosk. Akcelerometr mocowany magnetycznie $\mathrm{w}$ kierunku pionowym mierzy te same częstotliwości, co czujniki mocowane na wosk. Widmo zmierzonych sygnałów sięga do około $1 \mathrm{kHz}$; rzeczywiste jest raczej wyższe, natomiast ze względu na wstępną analizę literatury zastosowano sprzętowy filtr dolnoprzepustowy $1 \mathrm{kHz}$. Przejazd kół daje wymuszenie o szerokim paśmie częstotliwości; nie stwierdzono charakterystycznych pojedynczych częstotliwości pochodzących od prędkości obrotowej kół pociągu lub łożyskowania. Największe przemieszczenie drgań występuje, kiedy koła pociągu naciskają na szynę bezpośrednio nad czujnikami; częstotliwość tych drgań zależy od odległości pomiędzy poszczególnymi kołami i prędkości przejazdu pociągu. Na mierzonym odcinku przejazdu pociągu były to częstotliwości poniżej $10 \mathrm{~Hz}$.

$\mathrm{Z}$ analizy widma zmierzonych sygnałów wynika, że maksymalne wartości amplitud występują w zakresach częstotliwości znacznie oddalonych od wymaganych dla przetwornika $(150 \mathrm{~Hz})$. Nie należy się więc spodziewać efektywnej pracy przetworników, a co za tym idzie - uzyskiwania znaczących porcji energii.

Aby zweryfikować tak postawioną tezę, zainstalowano przetwornik drgania/napięcie w środowisku kolejowym i przeprowadzono bezpośrednie badania efektywności jego pracy. Na rys. 10 zaprezentowano omawiany przetwornik na stanowisku badawczym, zamocowany do szyny kolejowej.

Ze względów bezpieczeństwa oraz zgodnie ze ścisłymi regułami obowiązującymi na kolei przetwornik został zamocowany do szyny klejowej za pomocą sztywnych elementów pośredniczących, umożliwiających bezinwazyjny montaż i szybki demontaż. Analiza otrzymanych wyników była prowadzona zgodnie z przyjętymi założeniami:

1. Przez cały czas przejazdu składu generowana jest energia elektryczna o stałych parametrach wyznaczonych jako wartości szczytowe. Należy zaznaczyć, że jest to sytuacja idealna, niemająca odpowiednika $\mathrm{w}$ rzeczywistości technicznej. Została ona przyjęta jako wygodny wskaźnik porównawczy, dający ogólną orientację w spodziewanych uzyskach energii tworzonych przez badany przetwornik.

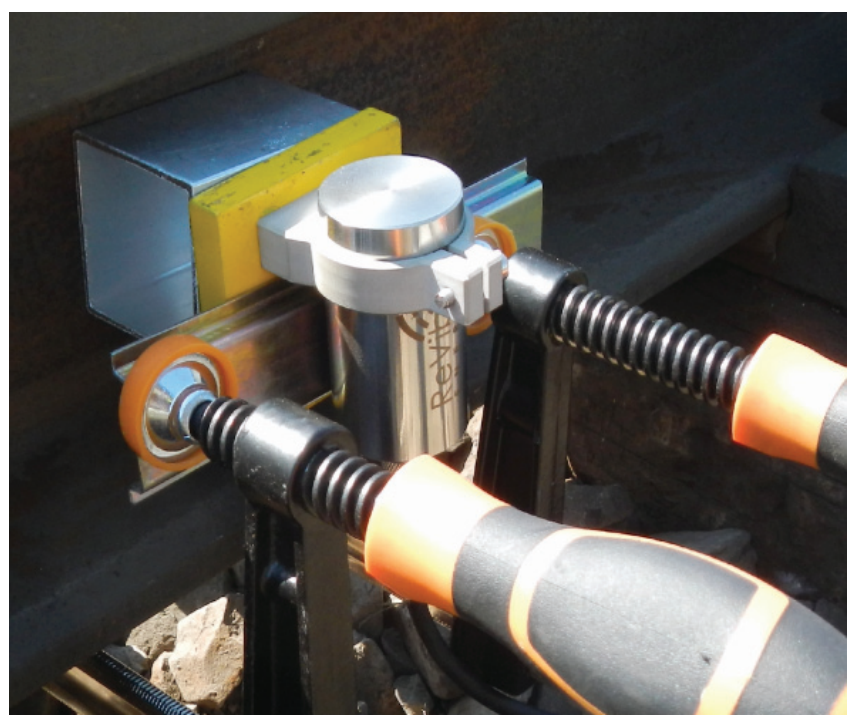

Fig. 10. Measurement station in real conditions

Rys. 10. Stanowisko do pomiarów w warunkach rzeczywistych 


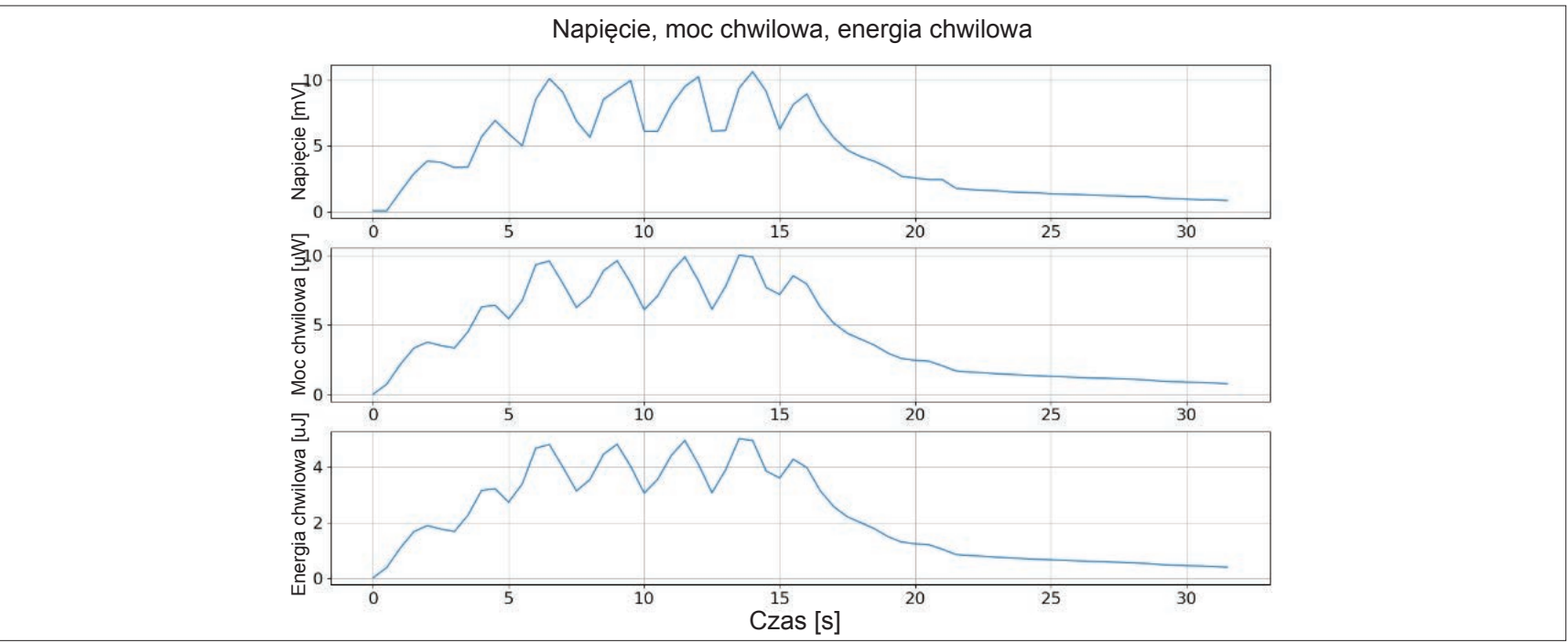

Fig. 11. Waveforms of generated voltage, power and energy

Rys. 11. Przebiegi generowanego napięcia, mocy i energii

2. Moc elektryczna prądu wyraża się wzorem: $P=U \cdot I$, gdzie $U$ - napięcie elektryczne w [V], $I$ - natężenie prądu $\mathrm{w}[\mathrm{A}]$, nie uwzględnia się żadnych strat energii elektrycznej.

3. Praca/energia, jaką wykonuje źródło prądu elektrycznego, jest wyrażona wzorem: $W=U \cdot q$, gdzie odpowiednio: $U$ - napięcie elektryczne w [V], $q$ - ładunek elektryczny w [C]. Natomiast $Q=I \cdot t$, gdzie $I$ - natężenie prądu w $[\mathrm{A}]$, a $t$ - czas $\mathrm{w}[\mathrm{s}]$. W rezultacie otrzymujemy wzór wynikowy: $W=U \cdot I \cdot t$, gdzie $W$ jest pracą prądu elektrycznego wyrażoną $\mathrm{w}$ [J].

$\mathrm{Na}$ rys. 11 przedstawiono przykładowy przebieg mierzonych parametrów podczas przejazdu składu kolejowego.

W zaprezentowanym przypadku napięcie mierzono $\mathrm{w}$ zakresie $\mathrm{mV}$ AC. Moc maksymalna wyniosła 1,274 $\mu \mathrm{W}$. Znak napięcia był stały dla całej serii pomiarowej. Na wykresie można wyróżnić oscylujące skoki napięcia w trakcie przejazdu pociaggu. Czas trwania pomiaru to $30 \mathrm{~s}$. Podczas badań z udziałem wielu różnych składów i pociągów nie udało się skorelować ze sobą otrzymywanych wyników. Nie było możliwe wyprowadzenie zależności, choćby statystycznej, między rodzajem (masą i długością) przejeżdżającego pociągu a charakterem przebiegów napięcia. Potwierdza to poczynione założenie, że przyjęte do badań środowisko wibracyjne jest zmienne i nieokreślone, co dobrze oddaje ewentualne warunki pracy przetwornika. Przetwornik generuje napięcie zmienne i moce osiągane przy odbiorniku przystosowanym do prądu stałego są przynajmniej o rząd wielkości niższe od napięć i mocy uzyskanych przy zakresie dla prądu przemiennego. Moce uzyskane z pomiarów są niewielkie, rzędu pojedynczych mikrowatów. Charakter przebiegów napięcia jest okresowo zmienny, napięcie ma zawsze ten sam znak, co oznacza, że napięcie jest tętniące.

\section{Wnioski}

Odbiornik, który będzie zasilany opisanym przetwornikiem drgania/napięcie, musi być przystosowany do magazynowania energii niesionej przez prąd o charakterze tętniącym. W praktyce oznacza to, że wydajność prądowa źródła będzie proporcjonalna do napięcia skutecznego odkładającego się na zaciskach przetwornika energii.

Moc generowana przez przetwornik w prezentowanych badaniach nie przekracza $2 \mu \mathrm{W}$. Przykładowo, standardowa płytka prototypowa $\mathrm{z}$ zabudowanym mikrokontrolerem z wyjściami i wejściami cyfrowymi oraz wejściami analogowymi może mieć pobór mocy rzędu co najmniej $10 \mathrm{~mW}$. Oznacza to, że do zasilenia takiego mikrokontrolera (przy założeniu ciągłej pracy przetwornika) należałoby w danych warunkach użyć 5000 przetworników.

Należy także zauważyć, że podczas pomiarów drgań szyn akcelerometrem $w$ trakcie przejazdu pociągu największa amplituda drgań (zatem największa energia mechaniczna) występowała dla częstotliwości wyższych niż $200 \mathrm{~Hz}$. Żaden producent nie ma w ofercie przetworników energii o takim punkcie pracy, są to zawsze wartości do $150 \mathrm{~Hz}$. Oznacza to, że przetwornik był z założenia niedopasowany do charakterystyki drgań generowanych przez przejeżdżający skład kolejowy. Według producenta jeden z wydajniejszych przetworników jest w stanie zapewnić moc $300 \mathrm{~mW}$ przy drganiach o dynamice $1 \mathrm{~g}$ i częstotliwości $60 \mathrm{~Hz}$. Moc taka byłaby wystarczająca do skutecznego zmagazynowania i zasilenia niewielkich układów elektronicznych, jednak żaden z tych warunków nie jest spełniony w rozpatrywanym środowisku kolejowym.

Trzeba pamiętać, że aby osiągnąć maksymalną wydajność przetwarzania drgań $w$ energię elektryczną za pomocą dedykowanego przetwornika, należy prowadzić jego wzbudzenie drganiami o zalecanej przez producenta częstotliwości. Trudno jednak wymagać, aby środowisko fizycznego procesu przemysłowego generowało drgania o częstotliwości ściśle określonej i niezmiennej w funkcji czasu. Dlatego potrzebne wydaje się przeprowadzenie testów w środowisku rzeczywistym, aby poznać i określić realne możliwości zastosowania wybranego przetwornika, co pozwoli na uniknięcie problemów z poprawną pracą urządzeń zasilanych tą metodą. 
Badania realizowane w ramach Projektu „BRIK Badania i Rozwój w Infrastrukturze Kolejowej", POIR.04.01.01-00-0002/17-00 w Programie Operacyjnym Inteligentny Rozwój (PO IR). Projekt współfinansowany przez Unię Europejską ze środków Europejskiego Funduszu Rozwoju Regionalnego.

\section{LITERATURA}

[1] Feynman R.P. "Atoms in Motion". Lectures on Physics. Vol. 1. California Institute of Technology (2010), ISBN: 978-0465-02414-8.

[2] Knight C., Davidson J., Behrens S. "Energy options for wireless sensor nodes". Sensors. 8 (2008): 8037-8066, https:// doi.org/10.3390/s8128037.

[3] Roundy S., Wright P.K., Rabaey J. "A study of low level vibrations as a power source for wireless sensor nodes". J. Comput. Commun. 26 (2002): 1131-1144, https://doi. org/10.1016/S0140-3664(02)00248-7.

[4] Shibata T., Iwaizumi, H. Fukuzumi, Y. et al. "Energy harvesting thermocell with use of phase transition". Sci Rep. 10, 1813 (2020), https://doi.org/10.1038/s41598-02058695-z.

[5] Anton S.R., Sodano H.A. "A review of power harvesting using piezoelectric materials (2003-2006)". Smart Mater. Struct.16 (2007): R1-R21, https://doi.org/10.1088/09641726/16/3/R01.

[6] Yogesh C., Padwekar P.S., Sharma P. et al., "Power Harvesting By Using Railway Vibrations (A Review)". International Journal of Engineering and Advanced Research Technology (IJEART). 2, 6 (June 2016), ISSN: 2454-9290.

[7] Akinaga H., Fujita H., Mizuguchi M. et al. "Focus on advanced materials for energy harvesting: prospects and approaches of energy harvesting technologies". Science and Technology of Advanced Materials. 19, 1 (2019): 543-544, https://doi.org/10.1080/14686996.2018.1491165.

[8] Szulewski P., Śnieguska-Gradzka D. „Systemy automatycznego monitorowania drgań w obrabiarkach". Mechanik. 3 (2017): 170-175, https://doi.org/10.17814/mechanik. 2017.3.37.

[9] Jasiulek D. „Propozycje zastosowania czujników samozasilających się w przemyśle wydobywczym”. Przegląd Górniczy. 70, 1 (2014): 9-15.

[10] "Smart sensors for monitoring machine energy use". Energy monitoring (November 5, 2020), https://www.pressac. com/insights/smart-sensors-for-monitoring-machine-energy-use/.

[11] Sodano H.A., Inman D.J., Park G. "A review of power harvesting from vibration using piezoelectric materials". Shock Vib. Dig. 36 (2004): 197-205, https://doi.org/ 10.1177/0583102404043275.

[12] Szulewski P., Śniegulska-Grądzka D., Nejman M. „Aktywne systemy monitorowania procesu skrawania dla Przemysłu 4.0". Mechanik. 91, 3 (2018): 183-189, https://doi. org/10.17814/mechanik.2018.3.34.

[13] Lallart M., Guyomar D., Jayet Y., Petit L., Lefeuvre E., Monnier T., Guy P., Richard C. "Synchronized switch harvesting applied to selfpowered smart systems: piezoactive microgenerators for autonomous wireless receiver". Sens. Actuators A: Phys. 147 (2008) 263-272, https://doi.org/10.1016/j.sna.2008.04.006.

[14] Garbuio L., Lallart M., Guyomar D., Richard C., Audigier D. "Mechanical energy harvester with ultralow threshold rectification based on SSHI nonlinear technique". IEEE Trans. Ind. Electron. 56 (2009): 1048-1056, https://doi. org/10.1109/TIE.2009.2014673.

[15] Sun H., Yin M., Wei W. et al. "MEMS based energy harvesting for the Internet of Things: a survey". Microsyst Technol. 24 (2018): 2853-2869, https://doi.org/10.1007/ s00542-018-3763-z.

[16] http://revibeenergy.com/wp-content/uploads/2020/ 03/ReVibeEnergy_General.pdf. 